\title{
Bandwidth Characteristics of Multimedia Data Traffic on a Local Area Network
}

Sherry L. Chuang, Sharon Doubek, and Richard F. Haines

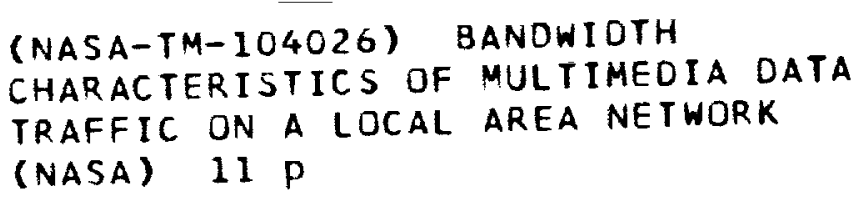

N94-15648

Unclas

$63 / 17 \quad 0190880$

September 1993

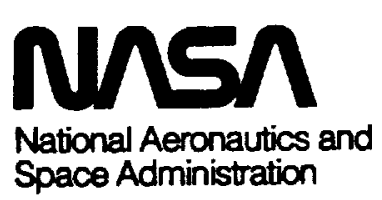


NASA Technical Memorandum 104026

\section{Bandwidth Characteristics of Multimedia Data Traffic on a Local Area Network}

Sherry L. Chuang, Ames Research Center, Moffett Field, California Sharon Doubek, Recom Technologies, San Jose, Califormia

Richard F. Haines, Ames Research Center, Moffett Field, California

September 1993

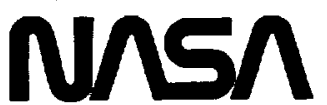

National Aeronautics and Space Administration 


\section{Summary}

Limited spacecraft communication links call for users to investigate the potential use of video compression and multimedia technologies to optimize bandwidth allocations. The objective of this study was to determine the transmission characteristics of multimedia data-motion video, text or bitmap graphics, and files transmitted independently and simultaneously over an ethernet local area network. Commercial desktop video teleconferencing hardware and software and Intel's proprietary Digital Video Interactive (DVI) video compression algorithm were used, and typical task scenarios were selected. The transmission time, packet size, number of packets, and network utilization of the data were recorded. First, each data type-compressed motion video, text and/or bitmapped graphics, and a compressed image file-was transmitted independently and its characteristics recorded. The results showed that an average bandwidth of 7.4 kilobits per second (kbps) was used to transmit graphics; an average bandwidth of $86.8 \mathrm{kbps}$ was used to transmit an 18.9-kilobyte (kB) image file; a bandwidth of $728.9 \mathrm{kbps}$ was used to transmit compressed motion video at 15 frames per second (fps); and a bandwidth of $75.9 \mathrm{kbps}$ was used to transmit compressed motion video at $1.5 \mathrm{fps}$. Average packet sizes were 93.3 bytes for graphics, 498.5 bytes for the image file, 345.8 bytes for motion video at $15 \mathrm{fps}$, and 341.9 bytes for motion video at 1.5 fps.

Secondly, simultaneous transmission of multimedia data types was also characterized. The multimedia packets used transmission bandwidths of $341.4 \mathrm{kbps}$ and 105.8 kbps. Bandwidth utilization varied according to the frame rate (frames per second) setting for the transmission of motion video. Packet size did not vary significantly between the data types.

When these characteristics are applied to Space Station Frecdom (SSF), the packet sizes fall within the maximum specified by the Consultative Committee for Space Data Systems (CCSDS). The uplink of imagery to SSF may be performed at minimal frame rates and/or within seconds of delay, depending on the user's allocated bandwidth. Further research to identify the acceptable delay interval and its impact on human performance is required. Additional studies in network performance using various video compression algorithms and integrated multimedia techniques are needed to determine the optimal design approach for utilizing SSF's data communications system.

\section{Introduction}

Methods for remote coaching and oversight of the onboard SSF crew members' activities by the groundbased Principal Investigators (PI) may require the exchange of science procedure checklists and data files. Science payload experimenters on SSF will also require video monitoring of their life science subjects. The number of video cameras and the amount of imagery that must be supported for science payloads exceeds the currently allocated data communications bandwidth of SSF. The transmission of these data types along with command and controls of environmental and engineering parameters in the payload facilities requires enough bandwidth to support two-way communication in order to facilitate high-quality performance. Transmission bandwidth will be limited because of the large numbers of payload functions required. An effective method to manage SSF's engineering, science, and payload command and control data transmission requirements must be found. It is necessary to investigate advanced technologies, such as video compression and methods for networking multimedia, to determine their feasibility for SSF.

Previous studies have shown that compressed remote video imagery is acceptable to the life sciences user community (ref. 1) and frame rates as low as 4 to 6 frames per second are acceptable for remote monitoring of small animals (ref. 2). The life sciences user community, comprised mostly of animal and plant physiologists and biologists, determined the acceptance levels of compressed imagery; they found that video compression technologies using a Joint Photographic Expert Group (JPEG) algorithm and a proprietary Discrete Cosine Transform (DCT) algorithm by Compression Laboratory Inc. (CLI) can support their scientific requirements. However, the engineering requirements to implement such a system call for weight, power, volume, and data bandwidth to be within SSF's engineering constraints.

\section{Method}

\section{Experiment Design and Variables}

This experiment used a two-node point-to-point configuration and transmitted three types of data: a two-way compressed motion video, a compressed video image file, and two-way text and graphics. A step-by-step procedure was designed for each data type and was systematically repeated during data collection. Data collection was done first by transmitting each of the data types independently, then simultaneously with another data type. For example, two-way motion video was transmitted at the same time a 
file was being transferred between workstations. Finally all three data types were transmitted simultaneously.

During each data-collection trial, the total number of packets, the total number of ethernet data bytes, the total transmission time in milliseconds, the packet size, and the percentage of bandwidth utilized were measured and recorded. A preliminary data-collection run was done with motion video in order to understand the effects of frame rate on the variability of network traffic. It confirmed that five trials per frame rate setting were sufficient, given that the variance between each trial was minimal; this finding allowed us to save time by reducing the number of data-collection trials per run. Therefore, five trials were performed for motion video data transmission, and ten trials were performed for file and graphical data in order to calculate a mean value.

\section{Apparatus}

All video imagery, graphics, and files were presented on a 16-inch (diagonal) computer screen of the IBM PS/2 model 80-321 computer. The computer has 10 megabyles (MB) of RAM and a $320 \mathrm{MB}$ hard disk. The video compression hardware consisted of Intel's ActionMedia II board set, an ActionMedia II Capture module with the ActionMedia II Delivery Board (attached as a daughter board) used to digitize and compress the National Television Standard Committee (NTSC) signal "on the fly" for display on the VGA monitor. ${ }^{1}$

IBM's video teleconferencing software, Person-to-Person (P2P), was used in conjunction with the ActionMedia II boards for this study. Person-lo-Person runs with IBM's OS/2's Presentation Manager and permits live video to be displayed locally, remotely, or in video conference mode. For this study, P2P was configured for the video conference mode. In addition to the video capability, the software also provides utilities such as "chalkboard" and "file transfer." The chalkboard utility provides a shared graphical workspace that participants can use to view, create, edit, point to, and share items from their computers. It has a drawing space, equipped with a set of tools for the production of simple colored graphics and text. The drawings done on the chalkboard appear on both participants' computer monitors simultaneously. The file transfer utility sends files between both Person-lo-Person users, provides progress information for file transfers, and informs users of incoming file transfers.

${ }^{1}$ ActionMedia Il boards digitize and compress a video signal for display on a monitor and/or storage on a hard disk. The boards uscd here cmployed a dual-chip, B-scrics i750 Video Display Processor.
A network-analyzer software package, Netminder, was installed on a Macintosh II attached to the same ethernet network as the two IBM PS/2 workstations (fig. 1). There were no other nodes on this ethernet segment. Netminder was used to collect data and to measure the traffic on the network; it recorded the number of total packets transmitted, the packet size, the total number of ethernet data bytes, the total transmission time in milliseconds, and the percentage of bandwidth utilized.

\section{Video Data Traffic}

Prerecorded video segments, described below, were played on a four-head, Heliquad II Model JR4500 VHS video cassette recorder whose video output was connected to the composite RS170 input connector of the ActionMedia II boards. The following video settings were configured through the P2P software: Tint $=50 \%$, Saturation $=76 \%$, Brightness $=66 \%$, Contrast $=50 \%$, and View $=$ single.

An onscreen frame rate control was used to set the frame rate in discrete steps between $15 \mathrm{fps}$ and $1.5 \mathrm{fps}$. The local and remote video scene was displayed in two video windows -128 by 120 pixels resolution-side by side on the computer monitor. The VGA monitor subtended 12.5 degrees (horizontally) by 9 degrees (vertically) of the user's visual field.

All video imagery was compressed by using a nine-bit hardware-based compression algorithm Digital Video Interactive (DVI) developed jointly by IBM and Intel Corporation. This compression algorithm divides each video frame into four-by-four pixel blocks and allocates each block one pixel representation. Each word consists of five bits for luminance, two bits for hue (color) and two bits for saturation. The algorithm is applied within each frame, i.e., there is no interframe encoding. Since the scenes presented were identical, the only parameter that changed from trial to trial was the frame rate.

Description of video scene- When video data collection was in progress, two-way video was transmitted between the PS/2 workstations. Each PS/2 workstation displayed its local video scene and the remote video scene in adjacent windows. The video scenes were prerecorded on color VHS and ran for two minutes. The recorded VHS images consisted of two white rats moving within a small enclosure similar to the animal holding habitats that may be used on SSF. The scenes consisted of both fast-motion and slow-motion activities. The slow-motion scene consisted of typical grooming activities (e.g., licking fur, scratching with a hind leg at about $6-10 \mathrm{~Hz}$, playfully biting each other). Neither animal walked around very much during the scene, but they exhibited typical slow 


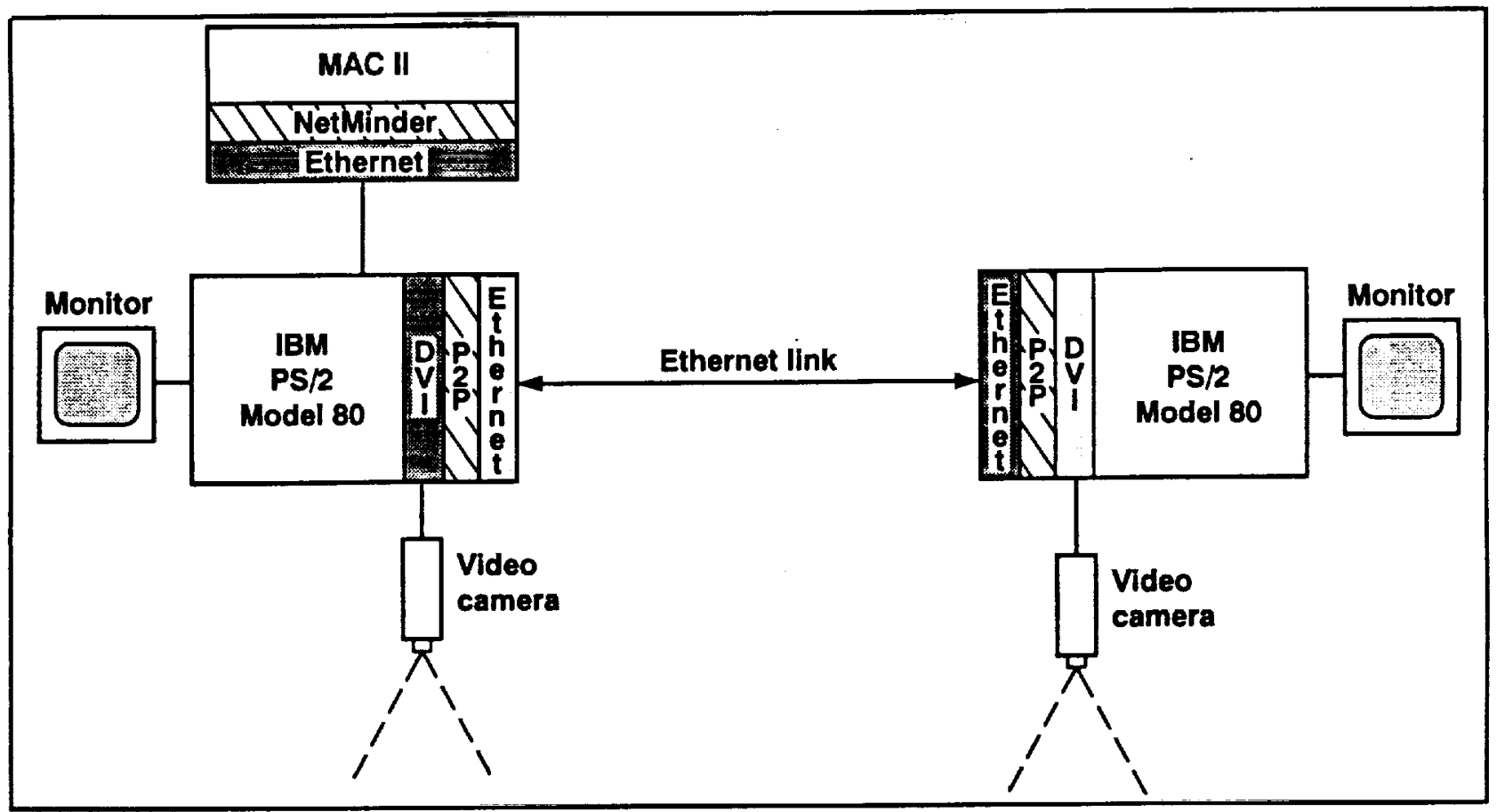

Figure 1. HW system diagram.

limb and body movement and exploratory behavior such as sniffing. The fast motion activity consisted of playful bchavior such as tumbling, chasing and rolling over cach other, and mock fighting. The angular rates of movement were so great that they appeared to be almost at the edge of blurring when viewed at $15 \mathrm{fps}$.

Procedure for video data collection- The vidco framc rates werc varicd from $1.5 \mathrm{fps}, 5 \mathrm{fps}, 10 \mathrm{fps}$, and $15 \mathrm{fps}$ whilc in the video conference modc. Five trials werc performed for cach frame rate and measurements werc recorded.

Results - The mcasurcments for the transmission of twoway motion vidco arc tabulated in table 1 . The mcans and standard deviation values werc calculated from the fivetrials-per-frame-ratc run. The network bandwidth is shown as a function of frame ratc in figurc 2 .

\section{Graphics Datu Truffic}

Procedure- The two uscrs cach sat in front of a PS/2 and simultancously used the chalkboard utility to draw and writc on a shared graphical document. The common document was displayed to both users while the collaborative task was being done in real timc. Each user was given an assignment to draw a ccrtain portion of the final document (fig. 3) with a predetermined tool and associated color. Each user announecd when he/she was finished with his/her section, and the data collector stopped the network monitor and recorded the measurements when both were finished. The time to completion obviously depended on the type of task and the users' familiarity with the task at hand; this task and the ratc of completion was selected to be representative of the type of interactive task that may be required in a remotc coaching scenario.

Results- The measurements taken when transmitting only graphical (chalkboard) data across the network are given in table 2. 
Table 1. Network traffic measurements for two-way video data between 1.5 fps and 15 fps

\begin{tabular}{|c|c|c|c|c|c|c|}
\hline & $\begin{array}{c}\text { Ethernet data } \\
\text { bytes }\end{array}$ & Total bytes & $\begin{array}{c}\text { Total time } \\
(\mathrm{sec})\end{array}$ & $\begin{array}{c}\text { Percent } \\
\text { bandwidth } \\
\text { utilized }\end{array}$ & $\begin{array}{c}\text { Packet size } \\
\text { (bytes) }\end{array}$ & kbps \\
\hline \multicolumn{7}{|l|}{$1.5 \mathrm{fps}$} \\
\hline Mcan & 1674458 & 1714575 & 180.0 & 0.76 & 341.93 & 75.90 \\
\hline $\begin{array}{l}\text { Standard } \\
\text { deviation }\end{array}$ & 35511 & 35817 & 1.2 & 0.02 & 4.89 & 1.85 \\
\hline \multicolumn{7}{|l|}{$5.0 \mathrm{fps}$} \\
\hline Mcan & 4952737 & 5071405 & 161.7 & 2.51 & 341.89 & 250.50 \\
\hline $\begin{array}{l}\text { Standard } \\
\text { deviation }\end{array}$ & 101737 & 103266 & 1.7 & 0.04 & 3.62 & 3.78 \\
\hline \multicolumn{7}{|l|}{$10 \mathrm{fps}$} \\
\hline Mcan & 10649196 & 10903272 & 161.6 & 5.39 & 343.31 & 539.20 \\
\hline $\begin{array}{l}\text { Standard } \\
\text { deviation }\end{array}$ & 215485 & 219022 & 4.8 & 0.11 & 2.86 & 11.12 \\
\hline \multicolumn{7}{|l|}{$15 \mathrm{fps}$} \\
\hline Mcan & 14387755 & 14779763 & 161.5 & 7.29 & 345.78 & 728.90 \\
\hline $\begin{array}{l}\text { Standard } \\
\text { deviation }\end{array}$ & 772357 & 706657 & 2.5 & 0.33 & 4.04 & 33.02 \\
\hline
\end{tabular}

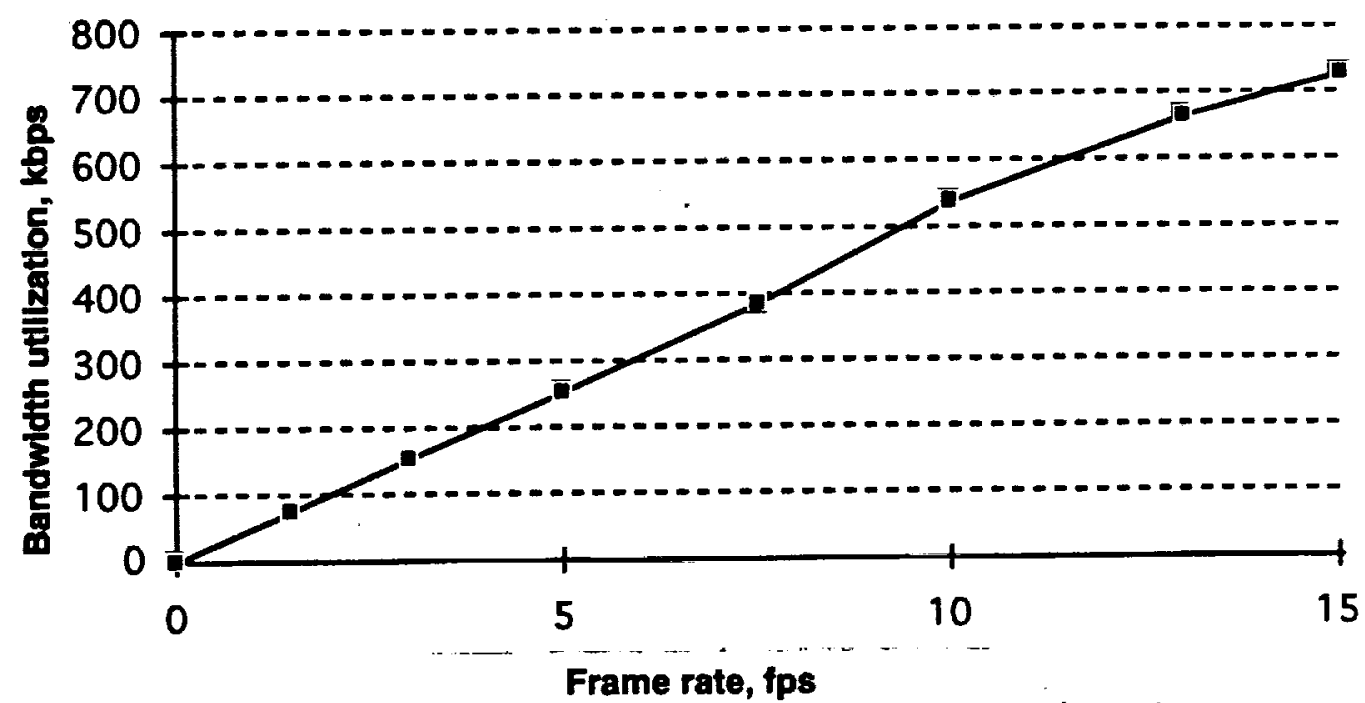

Figure 2. Network bandwidth as a function of frame rate. 


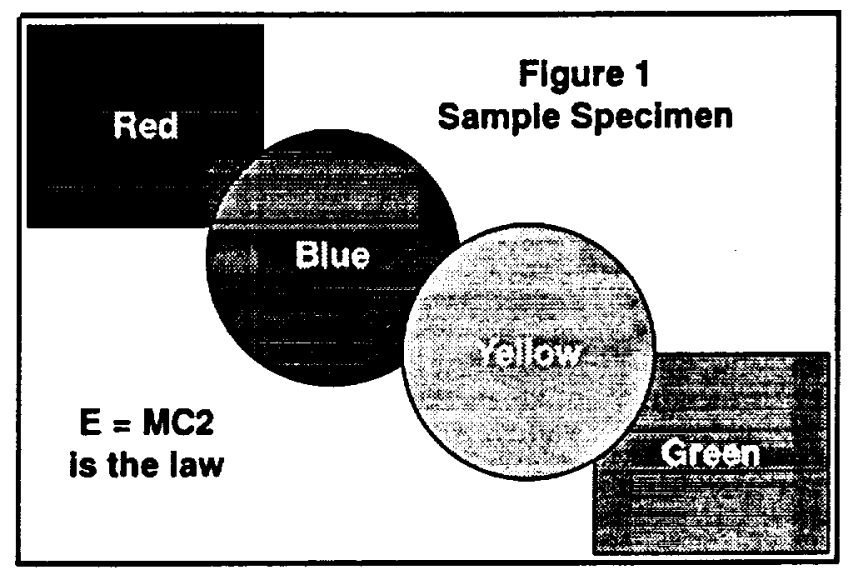

Figure 3. Representative graphics groupware document using P2P chalkboard.

Table 2. Network trafic measurements for graphics data

\begin{tabular}{lcccccc}
\hline \hline & $\begin{array}{c}\text { Ethernct data } \\
\text { bytcs }\end{array}$ & Total bytcs & $\begin{array}{c}\text { Total time } \\
(\mathrm{scc})\end{array}$ & $\begin{array}{c}\text { Pcrecnt } \\
\text { bandwidth } \\
\text { utilized }\end{array}$ & $\begin{array}{c}\text { Packet size } \\
\text { (bytcs) }\end{array}$ & kbps \\
\hline Mean & 31029.40 & 33605.00 & 34.6 & 0.07 & 93.27 & 7.40 \\
$\begin{array}{l}\text { Standard } \\
\text { deviation }\end{array}$ & 2361.49 & 2555.96 & 5.3 & 0.01 & 2.70 & 0.84 \\
\hline \hline
\end{tabular}

\section{File Data Trafic}

Procedure- Each uscr invoked the SEND FILE and RECEIVE FILE commands in P2P to transfer filcs betwecn the two PS/2 workstations. The filc was an image of a plant leaf with nccrosis in onc corncr magnificd 20X through a microscopc. The image displayed a range of chrominance vectors. It was capturcd at high resolution ( 640 widc by 480 high), digitizcd at DVI's 9-bit planc, compressed by using the JPEG algorithm, and resulted in a filc size of $18.9 \mathrm{kB}$ with a compression ratio of 51:1.

The SEND FILE command allowed one user to sclect the filc to be sent, specify the destination, and then transmit the filc over the network. The destination station would then receive a visual message on the computer monitor indicating that a filc had becn scnt. The message also prompted the uscr to use the RECEIVE FILE command to store and access the transmitted filc. The send/receive procedure for a filc of $18.9 \mathrm{kB}$ took approximatcly 25 scconds. The length of transmission time may change, depending upon the file sizc. ${ }^{2}$ Netminder collected data throughout the SEND FILE/RECEIVE FILE proccdurc.

Results- The measurements taken while sending a filc arc given in table 3.

\section{Integrated Multimedia Data Traffic}

The results are presented in tables 4-7 for aggregated multimedia data; combinations of graphics, vidco, and file data are varied systematically.

${ }^{2}$ Because the same two users performed the tasks, these SEND and RECEIVE FILE commands wcre completed in minimal time. Less experienced users may require more timc. 
Table 3. Network traffic measurements for file transfers

\begin{tabular}{lcccccc}
\hline & $\begin{array}{c}\text { Ethernet data } \\
\text { bytes }\end{array}$ & Total bytes & $\begin{array}{c}\text { Total time } \\
(\mathrm{sec})\end{array}$ & $\begin{array}{c}\text { Percent } \\
\text { bandwidth } \\
\text { utilized }\end{array}$ & $\begin{array}{c}\text { Packet size } \\
\text { (bytes) }\end{array}$ & kbps \\
\hline Mean & 228331.30 & 23204.10 & 2.5 & 0.87 & 498.52 & 86.80 \\
$\begin{array}{l}\text { Standard } \\
\text { deviation }\end{array}$ & 1375.47 & 1402.00 & 1.3 & 0.34 & 12.28 & 34.05 \\
\hline
\end{tabular}

Table 4. Network traffic measurements for simultaneous video and graphics data transmissions

\begin{tabular}{|c|c|c|c|c|c|c|}
\hline & $\begin{array}{c}\text { Ethemet data } \\
\text { bytes }\end{array}$ & Total bytes & $\begin{array}{l}\text { Total time } \\
(\mathrm{sec})\end{array}$ & $\begin{array}{c}\text { Percent } \\
\text { bandwidth } \\
\text { utilized }\end{array}$ & $\begin{array}{l}\text { Packet size } \\
\text { (bytes) }\end{array}$ & kbps \\
\hline \multicolumn{7}{|l|}{$1.5 \mathrm{fps}$} \\
\hline Mean & 258301.6 & & 25.7 & 0.83 & 245.85 & 82.6 \\
\hline $\begin{array}{l}\text { Standard } \\
\text { deviation }\end{array}$ & 17034.08 & & 2.2 & 0.03 & 3.81 & 2.97 \\
\hline \multicolumn{7}{|l|}{$5.0 \mathrm{fps}$} \\
\hline Mean & 876484.20 & & 29.8 & 2.42 & 285.82 & 241.6 \\
\hline $\begin{array}{l}\text { Standard } \\
\text { deviation }\end{array}$ & 106753.94 & 2555.96 & 4.4 & 0.07 & 2.75 & 6.91 \\
\hline \multicolumn{7}{|l|}{$10 \mathrm{fps}$} \\
\hline Mean & 1583937.60 & 1628593.60 & 30.6 & 4.24 & 292.24 & 424.40 \\
\hline $\begin{array}{l}\text { Standard } \\
\text { deviation }\end{array}$ & 94257.76 & 96920.77 & 1.4 & 0.18 & 4.54 & 18.35 \\
\hline \multicolumn{7}{|l|}{$15 \mathrm{fps}$} \\
\hline Mean & 1676776.80 & 1725583.20 & 33.3 & 4.14 & 283.26 & 413.60 \\
\hline $\begin{array}{l}\text { Standard } \\
\text { deviation }\end{array}$ & 114942.63 & 118371.69 & 1.4 & 0.14 & 3.03 & 14.19 \\
\hline
\end{tabular}


Table 5. Network traffic measurements for simultaneous video and file data transmissions

\begin{tabular}{|c|c|c|c|c|c|c|}
\hline & $\begin{array}{c}\text { Ethernet data } \\
\text { bytes }\end{array}$ & Total bytes & $\begin{array}{l}\text { Total time } \\
(\mathrm{sec})\end{array}$ & $\begin{array}{c}\text { Percent } \\
\text { bandwidth } \\
\text { utilized }\end{array}$ & $\begin{array}{l}\text { Packet size } \\
\text { (bytes) }\end{array}$ & kbps \\
\hline \multicolumn{7}{|l|}{$1.5 \mathrm{fps}$} \\
\hline Mcan & 265546.6 & 2771633 & 25.3 & 0.86 & 356.88 & 85.60 \\
\hline $\begin{array}{l}\text { Standard } \\
\text { deviation }\end{array}$ & 20161.83 & 20374.49 & 1.0 & 0.09 & 15.14 & 9.02 \\
\hline \multicolumn{7}{|l|}{$5 \mathrm{fps}$} \\
\hline Mcan & 671723.80 & 689002.20 & 26.5 & 2.07 & 319.08 & 207.00 \\
\hline $\begin{array}{l}\text { Standard } \\
\text { deviation }\end{array}$ & 95694.14 & 98001.84 & 2.7 & 0.11 & 2.90 & 10.91 \\
\hline \multicolumn{7}{|l|}{$10 \mathrm{fps}$} \\
\hline Mcan & 1278063.60 & 1284417.40 & 25.8 & 4.06 & 306.90 & 406.00 \\
\hline $\begin{array}{l}\text { Standard } \\
\text { deviation }\end{array}$ & 108238.40 & 102532.96 & 2.1 & 0.13 & 14.26 & 13.34 \\
\hline \multicolumn{7}{|l|}{$15 \mathrm{fps}$} \\
\hline Mcan & 1938703.00 & 1989768.60 & 31.3 & 5.08 & 312.51 & 507.80 \\
\hline $\begin{array}{l}\text { Standard } \\
\text { deviation }\end{array}$ & 310490.40 & 319538.88 & 5.1 & 0.11 & 6.89 & 11.39 \\
\hline
\end{tabular}

Table 6. Network traffic measurements for simultaneous graphics and file data transmissions

\begin{tabular}{lcccccc}
\hline \hline & $\begin{array}{c}\text { Ethernet data } \\
\text { bytes }\end{array}$ & Total bytes & $\begin{array}{c}\text { Total time } \\
(\mathrm{sec})\end{array}$ & $\begin{array}{c}\text { Percent } \\
\text { bandwidth } \\
\text { utilized }\end{array}$ & $\begin{array}{c}\text { Packet size } \\
\text { (bytes) }\end{array}$ & kbps \\
\hline Mean & 98830.8 & 102566.8 & 27.7 & 0.29 & 216.17 & 29.4 \\
$\begin{array}{l}\text { Standard } \\
\text { dcviation }\end{array}$ & 11496.06 & 11451.23 & 2.5 & 0.05 & 22.07 & 4.55 \\
\hline
\end{tabular}


Table 7. Network traffic measurements for simultaneous video, graphics, and file data transmissions

\begin{tabular}{|c|c|c|c|c|c|c|}
\hline & $\begin{array}{c}\text { Ethernet data } \\
\text { bytes }\end{array}$ & Total bytes & $\begin{array}{l}\text { Total time } \\
(\mathrm{sec})\end{array}$ & $\begin{array}{c}\text { Percent } \\
\text { bandwidth } \\
\text { utilized }\end{array}$ & $\begin{array}{l}\text { Packet size } \\
\text { (bytes) }\end{array}$ & kbps \\
\hline \multicolumn{7}{|l|}{$1.5 \mathrm{fps}$} \\
\hline Mcan & 471559.80 & 484380.60 & 36.5 & 1.06 & 302.07 & 105.80 \\
\hline $\begin{array}{l}\text { Standard } \\
\text { deviation }\end{array}$ & 46294.22 & 47315.77 & 3.9 & 0.03 & 5.94 & 3.35 \\
\hline \multicolumn{7}{|l|}{$5.0 \mathrm{fps}$} \\
\hline Mcan & 1172541.40 & 1202811.80 & 36.6 & 2.63 & 317.97 & 262.80 \\
\hline $\begin{array}{l}\text { Standard } \\
\text { deviation }\end{array}$ & 87963.71 & 90180.55 & 3.3 & 0.15 & 5.16 & 15.45 \\
\hline \multicolumn{7}{|l|}{$10 \mathrm{fps}$} \\
\hline Mcan & 1560939.60 & 1601035.60 & 37.4 & 3.41 & 319.37 & 341.40 \\
\hline $\begin{array}{l}\text { Standard } \\
\text { deviation }\end{array}$ & 160962.14 & 164715.61 & 2.2 & 0.18 & 6.62 & 18.11 \\
\hline \multicolumn{7}{|l|}{$15 \mathrm{fps}$} \\
\hline Mcan & 1254710.20 & 1286689.40 & 34.3 & 2.97 & 320.97 & 297.00 \\
\hline $\begin{array}{l}\text { Standard } \\
\text { deviation }\end{array}$ & 291431.49 & 298024.78 & 2.4 & 0.51 & 8.29 & 50.99 \\
\hline
\end{tabular}

\section{Discussion}

\section{Application to Space Station Freedom Operations}

Currently, the planned SSF communications downlink using the Tracking and Data Relay Satellite System (TDRSS) is 50 megabits per second (Mbps) through the $\mathrm{Ku}$ band and $192 \mathrm{kbps}$ through the S-band. The S-band uplink is $72 \mathrm{kbps}$. These communications links between the SSF and the ground use $4 \mathrm{kB}$ maximum CCSDS packets (ref. 3). This study of the multimedia network throughput indicates that compressed two-way video can be transmitted by using between 729 and $76 \mathrm{kbps}$, depending on the frame rate settings. Previous studies (ref. 4) have shown that frame rates of 4 to $6 \mathrm{fps}$ are acceptable for the life sciences community. Using simple arithmetic, we can expect one-way compressed video transmission to utilize about one-half of this bandwidth. The compressed video uses 343 bytes per packet, which is relatively small, and it fits within SSF uplink and downlink packet allocations. These small packets obviously need to be aggregated into larger CCSDS packets by the payload developers for compliance with SSF's communications guidelines.
The small-packel-size implementation of this video transmission algorithm has two advantages: digitized voice can also be synchronized and packetized per video data packet; and jitter can be reduced by spreading out jitter delays across more packet intervals. ${ }^{3}$ On the other hand, small-packet-size implementation has disadvantages because there is a higher probability of frame data loss in transmission. In the Fiber Distributed Data Interface (FDDI) protocol on SSF, dropped video frames are assumed to be permanently dropped.

Graphics and shared chalkboard tests determined an average data packet size of 93 bytes per packet and these packets can be accommodated within SSF uplink and downlink packet sizing. This sample task took an average of 34 seconds and used an average of $7.4 \mathrm{kbps}$ bandwidth. This work speed is typical of a ground-based PI working with an onboard crew member, so the bandwidth used was representative of the bandwidth allocation that would be needed for task completion in the future on SSF. If the $\mathrm{PI}$ and the crew member can work faster, then increased

\footnotetext{
${ }^{3}$ Maximum (inter-arrival delay) / \# of intervals in the data frame; max. (inter-arrival delay) is a function of FDDI tokcn passing parameter.
} 
bandwidth may be needed to reduce the frustration caused by communication delays.

Transmission of the image file used an average datapacket size of 498.5 bytes, well within the maximum CCSDS packet size of $4 \mathrm{kB}$. Space Station Freedom can support image file transmissions if the user can sustain the transmission delay. In this test the average bandwidth was $86.8 \mathrm{kbps}$ and the average send and receive completion time was $\mathbf{2 . 5}$ seconds. The transmission delay will vary, depending on the percentage of the $72 \mathrm{kbps}$ uplink bandwidth that is available to the transmission of the image file. It is not clear what would be an acceptable delay duration. Further human-factors research is needed to understand the impact of delay on science productivity.

\section{Conclusions}

We conclude from thesc findings that transmission of multimedia data across an ethernet local area network provides cvidence that the compression techniques used by commercial multimedia vendors can be adopted for SSF applications. A packet network can support aggrcgated multimedia data by using bandwidths as low as $729 \mathrm{kbps}$ for two-way transmission. A bandwidth of 310 kbps would be necded for vidco transmission at framc rates of 4 to $6 \mathrm{fps}$, which have becn shown in previous studics to be acceptable for the life sciences community. The question of delay also enters into the bandwidth equation. The acceptable delay interval and its impact on human performance will have to be defined and quantified empirically in order to request SSF bandwidth allocations and then optimize network usage.

\section{References}

1. Haines, R. F.; and Chuang, S. L.: The Effects of Video Compression on Acceptability of Images for Monitoring Life Scicnces' Expcriments. NASA TP-3239, 1992.

2. Haines, R. F.; and Chuang, S. L.: A Study of Vidco Frame Rate on the Pcrception of Compressed Dynamic Imagery. IEEE Data Compression Conference Procecdings, Snowbird, UT, March 1993.

3. Kohl, Ron: Payload Softwarc DMS Interfaccs. Presentation given at Payload Data Scrvices Workshop, Huntsvillc, AL, Aug. 5-6, 1992.

4. Chuang, S. L.; and Haines, R. F.: The Impact of Vidco Frame Ratc on Acceptablc Compressed Imagery and the Requirement for Network Throughput. Socicty for Information Displays (SID) Digcst '93, Scattlc, WA, 1993. 
Public reporting burden for this collection of information is estimaled to average 1 hour per response, including the time for reviewing instructions, searching exlsting data sources,

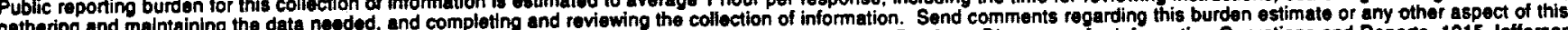
gathering and maintaining the date need, and corpering this burden, to Washington Headquarters Services, Directorate for Information Operations and Repons, 1215 Jefferson collection of

\begin{tabular}{|l|l|l|l}
\hline 1. ACENCY USE ONLY (Leave blank) & 2. REPORT DATE & 3. REPOAT TYPE AND DATES COVERED
\end{tabular}

September 1993

Technical Memorandum

4. TITLE AND SUBTITLE

Bandwidth Characteristics of Multimedia Data Traffic on a Local

Area Network

6. AUTHOR(S)

Sherry L. Chuang, Sharon Doubek, and Richard F. Haines

7. PERFORMING ORgaNIZATION NAME(S) AND ADDRESS(ES)

8. PERFORUING ORGANIZATION REPORT NUMBER

Ames Research Center

Moffett Field, CA 94035-1000

A-93088

9. SPONSORING/MONITORING AGENCY NAME(S) AND ADDRESS(ES)

10. SPONSORING/MONITORING

AGENCY REPORT NUMBER

National Aeronautics and Space Administration

Washington, DC 20546-0001

NASA TM-104026

11. SUPPLEMENTARY NOTES

Point of Contact: Sherry Chuang, Ames Research Center, MS 269-4, Moffett Field, CA 94035-1000 (415) 604-3376

12a. DISTRIBUTION/AVAILABILITY STATEMENT

2b. DISTAIBUTION CODE

Unclassified-Unlimited

Subject Category - 17

13. ABSTRACT (Maxlmum 200 words)

Limited spacecraft communication links call for users to investigate the potential use of video compression and multimedia technologies to optimize bandwidth allocations. The objective of this study was to determine the transmission characteristics of multimedia data-motion video, text or bitmap graphics, and files transmitted independently and simultaneously over an ethernet local area network. Commercial desktop video teleconferencing hardware and software and Intel's proprietary Digital Video Interactive (DVI) video compression algorithm were used, and typical task scenarios were selected. The transmission time, packet size, number of packets, and network utilization of the data were recorded. Each data type-compressed motion video, text and/or bitmapped graphics, and a compressed image file-was first transmitted independently and its characteristics recorded. The results showed that an average bandwidth of 7.4 kilobits per second (kbps) was used to transmit graphics; an average bandwidth of $86.8 \mathrm{kbps}$ was used to transmit an 18.9-kilobyte $(\mathrm{kB})$ image file; a bandwidth of $728.9 \mathrm{kbps}$ was used to transmit compressed motion video at 15 frames per second (fps); and a bandwidth of $75.9 \mathrm{kbps}$ was used to transmit compressed motion video at 1.5 fps. A verage packet sizes were 93.3 bytes for graphics, 498.5 bytes for the image file, 345.8 bytes for motion video at $15 \mathrm{fps}$. and 341.9 bytes for motion video at 1.5 fps.

Simultaneous transmission of multimedia data types was also characterized. The multimedia packets used transmission bandwidths of $341.4 \mathrm{kbps}$ and $105.8 \mathrm{kbps}$. Bandwidth utilization varied according to the frame rate (frames per second) setting for the transmission of motion video. Packer size did not vary significantly between the data types.

When these characteristics are applied to Space Station Freedom (SSF), the packet sizes fall within the maximum specified by the Consultative Committee for Space Data Systems (CCSDS). The uplink of imagery to SSF may be performed at minimal frame rates and/or within seconds of delay, depending on the user's allocated bandwidth. Further research to identify the acceptable delay interval and its impact on human performance is required. Additional studies in network performance using various video compression algorithms and integrated multimedia techniques are needed to determine the optimal design approach for utilizing SSF's data communications system.

14. SUBJECT TERMS

Video compression, Multimedia, Networks

15. NUMBER OF PAGES

16. PRICE CODE

$\mathrm{A} 02$

\begin{tabular}{l|l|l} 
17. SECURITY CLASSIFICATION & 18. SECURTY CLASSIFICATION \\
OF TEPORT & $\begin{array}{l}\text { 19. SECUAITY CLASSIFICATION } \\
\text { OF ABSTRACT } \\
\text { Unclassified }\end{array}$
\end{tabular}

20. LIMITATION OF ABSTRACT 